\title{
Effects of corticosterone and dietary changes in the hen on ovarian function, plasma LH and steroids and the response to exogenous LH-RH
}

\author{
R. J. Etches*, J. B. Williams and J. Rzasa $\dagger$ \\ Station de Recherches Avicoles, I.N.R.A. Centre de Tours-Nouzilly, 37380 Monnaie, France
}

\begin{abstract}
Summary. Ovarian regression was induced in hens by infusing $30 \mu \mathrm{g}$ corticosterone $/ \mathrm{h}$, feeding diets deficient in $\mathrm{Ca}^{2+}$ or $\mathrm{Na}^{+}$and by withdrawal of food and water. The weight of the ovary was most severely reduced by the corticosterone infusion. The total number of normal ovarian follicles weighing $>0.012 \mathrm{~g}$ was not altered by any of the treatments. However, the number of large yolk-filled follicles decreased while the numbers of smaller follicles and atretic follicles increased when ovarian regression was induced by dietary changes or hormone infusion as compared to normally fed or solvent-infused hens.

These experimental treatments resulted in decreases in plasma concentrations of LH, progesterone and oestradiol, and increases in the plasma levels of corticosterone. These changes were immediate except for the low sodium diet with which there was a delay of about 6 days. When fasted birds were fed oats and given water, plasma LH and oestradiol, but not progesterone, increased. The infusion of corticosterone did not affect the ability of the pituitary gland to secrete $\mathrm{LH}$ after an injection of $\mathrm{LH}-\mathrm{RH}$, but this response was reduced or eliminated by the other experimental treatments. It is concluded that the regression of the ovary induced by these experimental treatments is a consequence of the reduction in the secretion of $\mathrm{LH}$, which may itself be caused by increased plasma levels of corticosterone. It also appears that recruitment of follicles in the maturational stage which precedes entry into the hierarchy of large yolky follicles was unaffected by all of the methods of inducing ovarian regression which were studied.
\end{abstract}

\section{Introduction}

It has been suggested that there is an interaction between the adrenal gland and ovarian function in the hen. For example, injections of ACTH, corticosterone or deoxycorticosterone will induce ovulation (van Tienhoven, 1961; Etches \& Cunningham, 1976) and LH release (Wilson \& Sharp, 1976a, Etches \& Croze, 1983), injections of dexamethasone will inhibit ovulation and LH release (Soliman \& Huston, 1974; Wilson \& Lacassagne, 1978) and injections of metyrapone will alter the normal timing of LH release (Wilson \& Cunningham, 1981). However, the relevance of the adrenal to normal ovarian function is difficult to test because the amount of corticosterone or ACTH

* Present address: Department of Animal and Poultry Science, University of Guelph, Guelph, Ontario, Canada N1G 2 W1.

† Present address: Department of Animal Physiology, Academy of Agriculture, 30-059 Krakow, Al. Mickiewicza 24/28, Poland. 
required to induce ovulation exceeds the normal physiological range (Sharp \& Beuving, 1978; Etches \& Croze, 1983). Furthermore, the physiological interpretation of the effects of drugs such as dexamethasone and metyrapone is complicated by the lack of knowledge of their target tissues and their complete array of effects.

We have therefore examined the effects of a constant infusion of a quantity of corticosterone sufficient to raise the plasma concentrations within the normal physiological range, and compared them to those induced by dietary deficiency of calcium or sodium or by withdrawal of food and water. A study was made of changes in the ovary, in plasma levels of luteinizing hormone (LH) and ovarian steroids, and in the response of the pituitary gland to LH-RH during the experimental period.

\section{Materials and Methods}

\section{Animals and experimental design}

Warren SSL hens in their 6th month of lay were selected for this experiment on the basis of normal rates of egg production and body weight. The 70 hens were maintained in a lighting regimen of $14 \mathrm{~h}$ light : $10 \mathrm{~h}$ dark (lights on at $05: 00-19: 00 \mathrm{~h}$ ) and provided with a normal laying hen diet and water ad libitum. Egg production was recorded daily for each hen. After 7 days the birds were randomly assigned to 7 treatment groups of 10 birds each: Group 1, controls; Group 2 hens were fed on a diet containing $<0.23 \mathrm{~g}$ sodium $/ \mathrm{kg}$ food; Group 3 hens received a diet containing $0.9 \mathrm{~g}$ calcium $/ \mathrm{kg}$ food; Group 4 hens were deprived of food and water during Days 1, 2, 4, 6 and 8, and given whole oats and water on Days 3, 5, 7 and 9 and a normal laying hen diet and water $a d$ libitum from Days 10 to 14; in Group 5 the hens were implanted with an Osmotic Mini Pump (Model 2ML2, Alzet Corp., Palo Alto, CA, U.S.A.) delivering $5 \mu 1$ polyethylene glycol 400 (Merck, Hohenbrunn, West Germany)/h; in Group 6 the hens received a mini-pump implant delivering $30 \mu \mathrm{g}$ corticosterone (Sigma Chem. Co. Ltd, St Louis, MO, U.S.A.) dissolved in $5 \mu$ l polyethylene glycol 400/h; Group 7 hens had a mini-pump implant delivering $10 \mu \mathrm{g}$ corticosterone dissolved in $5 \mu$ polyethylene glycol $400 / \mathrm{h}$.

The pumps were placed subcutaneously on the dorsal aspect of the neck. The normal diet was provided for the infused hens. The concentrations of corticosterone infused were determined from a pilot study in which 3 groups of 3 birds received 120,60 or $30 \mu \mathrm{g}$ corticosterone/h via a mini-pump and the plasma concentrations of corticosterone in blood withdrawn daily were determined by radioimmunoassay (RIA) over a 2 -week period.

\section{Blood sampling protocols}

Six birds were chosen at random from each treatment group for the study of hormone levels in the plasma; $5 \mathrm{ml}$ blood were collected in a heparinized syringe from a wing vein 2 days before and at the onset of the experimental treatments and on Days 1, 2, 3, 5, 7, 9, 11 and 13. Hens in Group 4 were also sampled on Days 4, 6 and 8. All blood samples were taken in the afternoon. On the afternoon of Day 12 or 14,5 birds from each group were injected with $0.5 \mathrm{ml} 0.15 \mathrm{M}-\mathrm{NaCl}$ and $2 \mathrm{ml}$ blood samples were collected before and at 5,10 and $30 \mathrm{~min}$ after injection. Immediately after the 30-min blood sample, hens received an i.v. injection of synthetic LH-RH (Hoechst Pharmaceuticals, Frankfurt, West Germany) dissolved in $0.15 \mathrm{M}-\mathrm{NaCl}(25 \mu \mathrm{g} / \mathrm{kg}$ body weight $)$ and further 2-ml blood samples were obtained 5, 10 and 30 min thereafter.

Plasma obtained by centrifugation was stored at $-20^{\circ} \mathrm{C}$ until required for hormone assays.

\section{Hormone assays}

$L H$. Samples of 50 and $100 \mu \mathrm{l}$ were assayed in duplicate according to the method of Follett, Scanes \& Cunningham (1972) using fraction IRC2 as the labelled hormone, AEI as standard and an 
antiserum (15/8) raised against fraction $\mathrm{CM}_{2}$. The mean intra-assay variation was $9 \cdot 7 \%$ and the interassay variation for the 4 assays used in this study was $12.0 \%$. The $\mathrm{ED}_{50}$ (mean $\pm \mathrm{s}$.d.) of the fitted standard curve was $187 \pm 45 \cdot 8 \mathrm{pg}$.

Oestradiol. Oestradiol was assayed using the specific antiserum described by Dray et al. (1971) at a final dilution of $1 / 180000$ in a total incubation volume of $300 \mu$ phosphate-buffered saline $(0 \cdot 1 \mathrm{M}, \mathrm{pH} 7)$ and $\left[2,4,6,7-{ }^{3} \mathrm{H}\right]$ oestradiol (Amersham France S.A., Les Ulis, France) as radioactive ligand. Activated charcoal $(0 \cdot 1 \%)$ was used to separate bound and free fractions. After centrifugation ( $10 \mathrm{~min}, 1200 \mathrm{~g}, 4^{\circ} \mathrm{C}$ ), the supernatant was decanted into a vial containing $1 \mathrm{ml}$ ethanol (Prolabo, Paris, France); $5 \mathrm{ml}$ toluene scintillator (Packard Instruments, Rungis, France) were added to each vial and counting was performed $24 \mathrm{~h}$ later. Under these conditions, the binding in zero tubes expressed as a percentage of the total radioactivity was $39 \cdot 2 \pm 3 \cdot 6 \%$ (mean \pm s.d.). Plasma samples $(600 \mu \mathrm{l})$ were assayed in duplicate after extraction with 5 volumes of dichloromethane (Analytical Grade, Merck, Hohenbrunn, West Germany). The mean recovery of $\left[{ }^{3} \mathrm{H}\right]-$ oestradiol was $63.2 \%$ and the range of the standard curve of oestradiol (Sigma) was $6 \cdot 25-400 \mathrm{pg}$. The assay was validated by adding increasing amounts of oestradiol to a pool of plasma from laying hens, and the equation of the regression line obtained was $y=0.96 x+20 \cdot 0$. The coefficients of intra- and interassay variation for the assays used in this study were 11.5 and $15.2 \%$, respectively. The $\mathrm{ED}_{50}$ (mean \pm s.d.) of the fitted standard curve was $51 \cdot 2 \pm 9 \cdot 2 \mathrm{pg}$.

Progesterone and corticosterone. Progesterone was assayed by the method of Duplaix, Williams \& Mongin (1981) and corticosterone according to Etches (1976). The coefficients of intra- and interassay variance were $11.5 \%$ and $17.6 \%$ (progesterone) and $12.6 \%$ and $14.6 \%$ (corticosterone), respectively. The $\mathrm{ED}_{50}$ measurements (mean \pm s.d.) for the fitted standard curve were $99.0 \pm$ $25.4 \mathrm{pg}$ (progesterone) and $117 \pm 29 \cdot 8 \mathrm{pg}$ (corticosterone).

\section{Analyses at autopsy}

On Day 14, the hens were killed by cervical dislocation and the weights of the ovaries were taken. From each ovary, all follicles with diameters greater than $2.5 \mathrm{~mm}$ and/or weighing more than $12 \mathrm{mg}$ were dissected and their diameter and weights were recorded. These data were ranked and grouped into four classes of follicular size. Classes were determined by least squares regression analysis of the entire control group data (best fit line: $\log \mathrm{P}=a+b \log \mathrm{W}, r=0.958$ where $\mathrm{P}=$ position of follicle in the hierarchy, $\mathrm{W}=$ weight of follicle) and were chosen to include the first, second, third and fourth decades of the hierarchy of ovarian follicles. For each individual hen, least squares regression analysis was performed to determine the slope, $b$, and the $y$-axis intercept, $a$, of the $\log \mathrm{P}=a+b \log \mathrm{W}$ relationship $(0.87<r<0.98$; minimum \& maximum) for the $n$ follicles found in the range $12-250 \mathrm{mg}$. The quantities $a, b$ and $n$ were utilized in statistical analysis. 'Atretic' follicles, i.e. deformed and/or discoloured yolky follicles, were removed from the ovary and counted. The weight of the remaining ovarian tissue (termed 'stroma') was recorded. Statistical analyses were performed using principal component analysis, an appropriate analysis of variance (1-way or 2-way) and Duncan's Multiple Range test or linear contrasts.

\section{Results}

\section{Determination of the infusion rate of corticosterone}

The pilot study revealed that the infusion of $30 \mu \mathrm{g}$ corticosterone/h produced a mean plasma level of $3.37 \mathrm{ng} / \mathrm{ml}$ plasma over a 2-week period after implantation of the mini-pump. This is within the physiological range of plasma concentrations of corticosterone in the laying hen (Etches, 1976; Sharp \& Beuving, 1978; Wilson \& Cunningham, 1980). Infusions at rates of 30 and $10 \mu \mathrm{g} / \mathrm{h}$ were therefore used for the main study. The higher infusion rates $(60$ and $120 \mu \mathrm{g} / \mathrm{h}$ ) resulted in supraphysiological plasma corticosterone levels (mean plasma levels 4.52 and $7.25 \mathrm{ng} / \mathrm{ml}$ respectively). All of the infusion rates prevented laying within 3-4 days.ded from Bioscientifica.com at 04/26/2023 06:35:06AM 


\section{Egg production}

No changes in egg production were noted in the hens in Groups 1 and 5, and a slight decline in production was noted in Group 7 on Days 13 and 14. By contrast, the rate of production of the hens in Group 6 fell on Day 3 after implantation and no eggs were laid after Day 8 . The hens in Groups 3 and 4 also had reduced egg production on Day 3 although one Group 4 hen continued to lay throughout the 14 days. The rate of egg production also declined in Group 2 although the decline was 1 week later than in Groups 3, 4 and 6.

\section{Ovarian weights (Table 1)}

After 14 days of treatment, total ovarian weight was identical in hens in Groups 1, 5 and 7 (range $48 \cdot 3-60 \cdot 0 \mathrm{~g}$ ), and reduced by $\sim 5 \%$ in the hens in Groups 2,3 and 4 and by $\sim 90 \%$ in Group 6 . The change in the weight of the ovarian stroma followed the same pattern as the change in total ovarian weight.

Table 1. Mean weights of the ovary with and without the largest follicles, the numbers of large follicles, their classification by class size and the number of atretic follicles in the ovaries of hens subjected to a dietary treatment or infused with corticosterone (all measurements 14 days after the initiation of the treatments)

\begin{tabular}{|c|c|c|c|c|c|c|c|c|}
\hline & \multicolumn{7}{|c|}{ Group* } & \multirow{2}{*}{$\begin{array}{l}\text { Standard } \\
\text { deviation }\end{array}$} \\
\hline & 1 & 2 & 3 & 4 & 5 & 6 & 7 & \\
\hline \multicolumn{9}{|l|}{ Total ovarian weight } \\
\hline & $53.97^{\mathrm{a}}$ & $22 \cdot 21^{\text {cd }}$ & $29 \cdot 27^{b c d}$ & $24 \cdot 55^{\mathrm{bcd}}$ & $48 \cdot 28^{\mathrm{ab}}$ & $6 \cdot 44^{d}$ & $48 \cdot 41^{a b}$ & $17 \cdot 67$ \\
\hline (stroma) weight (g) & $3 \cdot 18^{3}$ & $2 \cdot 19^{\mathrm{bc}}$ & $2 \cdot 58^{\mathrm{ab}}$ & $2 \cdot 30^{\mathrm{bc}}$ & $2 \cdot 75^{\mathrm{ab}}$ & $1.80^{\mathrm{c}}$ & $2 \cdot 63^{\mathrm{ab}}$ & $0 \cdot 54$ \\
\hline \multicolumn{9}{|l|}{ Total no. of follicles } \\
\hline$>12 \mathrm{mg}$ & $24 \cdot 0^{\mathrm{abc}}$ & $20 \cdot 6^{b c}$ & $31 \cdot 1^{a}$ & $28 \cdot 2^{\mathrm{a}}$ & $19 \cdot 4^{\mathrm{bc}}$ & $24 \cdot 2^{\mathrm{abc}}$ & $30 \cdot 2^{a}$ & $6 \cdot 1$ \\
\hline No of atretic follicles & $4 \cdot 2^{y z}$ & $8 \cdot 2^{x}$ & $6 \cdot 9^{x y}$ & $7 \cdot 7^{\mathrm{x}}$ & $3 \cdot 0^{2}$ & $8 \cdot 1^{x}$ & $3 \cdot 7^{2}$ & $3 \cdot 0$ \\
\hline \multicolumn{9}{|l|}{ Follicle numbers } \\
\hline Class $1>250 \mathrm{mg}$ & $31 \cdot 7^{a}$ & $10 \cdot 0^{\mathrm{bx}}$ & $11 \cdot 7^{\mathrm{bc}}$ & $18 \cdot 2^{\mathrm{b}}$ & $37 \cdot 0^{3}$ & $2 \cdot 2^{\mathrm{a}}$ & $20 \cdot 0^{\mathrm{b}}$ & $8 \cdot 0$ \\
\hline Class $2>55-250 \mathrm{mg}$ & $47.9^{\mathrm{a}}$ & $41 \cdot 7^{\mathrm{a}}$ & $35 \cdot 8^{x}$ & $36 \cdot 3^{a}$ & $45 \cdot 1^{\text {* }}$ & $33 \cdot 9^{\mathrm{a}}$ & $38 \cdot 3^{a}$ & $14 \cdot 2$ \\
\hline Class $3>22-55 \mathrm{mg}$ & $17.9 \mathrm{bc}$ & $35 \cdot 7^{\mathrm{ab}}$ & $32 \cdot 6^{\mathrm{ab}}$ & $30 \cdot 8^{a b c}$ & $14 \cdot 7^{\mathrm{c}}$ & $40 \cdot 0^{a}$ & $32 \cdot 2^{\mathrm{ab}}$ & $12 \cdot 3$ \\
\hline Class $4>12-22 \mathrm{mg}$ & $2 \cdot 5^{b}$ & $12 \cdot 6^{\mathrm{ab}}$ & $19 \cdot 9^{\mathbf{a}}$ & $14 \cdot 7^{\mathrm{ab}}$ & $3 \cdot 2^{b}$ & $23 \cdot 9^{a}$ & $9 \cdot 5^{\mathrm{ab}}$ & 9.9 \\
\hline
\end{tabular}

abod Means with the same superscript are not significantly different $(P<0.01)$.

${ }^{x y z}$ Means with the same superscript are not significantly different $(P<0.05)$.

* Group $1=$ control; Group $2=$ low $\mathrm{Na}^{+} \operatorname{diet} ;$ Group $3=$ low $\mathrm{Ca}^{2+} \operatorname{diet}$; Group $4=$ food and water deprivation; Group $5=5 \mu \mathrm{l}$ polyethyleneglycol $400 / \mathrm{h}$; Group $6=30 \mu \mathrm{g}$ corticosterone $/ \mathrm{h}$; Group $7=10 \mu \mathrm{g}$ corticosterone $/ \mathrm{h}$.

\section{Follicular hierarchy (Table 1)}

Although differences in the mean number of follicles heavier than $12 \mathrm{mg}$ were observed between the various treatment groups, the means were never significantly different from the mean number of follicles found in the control hens (Groups 1 and 5) (Table 2). By contrast, significantly more atretic follicles were observed in the hens in Groups 2, 3, 4 and 6.

The distribution of normal follicles weighing over $12 \mathrm{mg}$ within the hierarchy differed between groups. In hens that continued to lay normally (Groups 1, 5 and 7), 20-35\% of the follicles were in the largest weight class (class 1 ) and, for Groups 1 and 5, this was significantly more than in hens in Groups 2, 3, 4 and 6 which stopped laying. No differences were found for class 2 follicles, but the hens that had ceased laying (Groups 2, 3, 4 and 6) tended to have more smaller follicles than did control hens (Groups 1 and 5). These differences were significant in class 4 (smallest follicles) for the hens in Group 6. 
Table 2. Mean \pm s.d. $(n=5)$ plasma LH concentrations $(\mathrm{ng} / \mathrm{ml})$ in experimental hens after an injection of saline and LH-RH

\begin{tabular}{|c|c|c|c|c|c|c|c|c|}
\hline \multirow[b]{2}{*}{ Group } & \multicolumn{7}{|c|}{ Time (min) } & \multirow[b]{2}{*}{ Significance* } \\
\hline & 0 & 5 & 10 & 30 & 35 & 40 & 60 & \\
\hline I (control) & $\begin{array}{r}0.89 \\
+0.43\end{array}$ & $\begin{array}{r}0.97 \\
\pm 0.47\end{array}$ & $\begin{array}{r}1.18 \\
\pm 0.32\end{array}$ & $\begin{array}{r}1.08 \\
\pm 0.35\end{array}$ & $\begin{array}{r}1.85 \\
\pm 0.57\end{array}$ & $\begin{array}{r}2.02 \\
\pm 0.76\end{array}$ & $\begin{array}{r}2.01 \\
\pm 0.83\end{array}$ & $P<0.001$ \\
\hline 2 (low sodium) & $\begin{aligned} & 1.27 \\
\pm & 0.4\end{aligned}$ & $\begin{array}{r}1.14 \\
\pm 0.31\end{array}$ & $\begin{array}{r}1.00 \\
\pm 0.55\end{array}$ & $\begin{array}{r}0.96 \\
\pm 0.39\end{array}$ & $\begin{array}{r}1.47 \\
\pm 0.94\end{array}$ & $\begin{array}{r}1.63 \\
\pm 1.23\end{array}$ & $\begin{array}{r}1.64 \\
+0.77\end{array}$ & NS \\
\hline 3 (low calcium) & $\begin{array}{r}0.61 \\
\pm 0.57\end{array}$ & $\begin{array}{r}0.71 \\
\pm 0.54\end{array}$ & $\begin{array}{r}0.71 \\
\pm 0.86\end{array}$ & $\begin{aligned} & 0.66 \\
\pm & 0.6\end{aligned}$ & $\begin{aligned} & 1.07 \\
+ & 0.7\end{aligned}$ & $\begin{array}{r}1.11 \\
+0.82\end{array}$ & $\begin{array}{r}1.20 \\
+0.64\end{array}$ & NS \\
\hline 4 (fasted) & $\begin{array}{r}0.64 \\
\pm 0.27\end{array}$ & $\begin{array}{r}0.78 \\
+0.33\end{array}$ & $\begin{array}{r}0.44 \\
\pm 0.25\end{array}$ & $\begin{array}{r}0.64 \\
\pm 0.31\end{array}$ & $\begin{array}{r}0.69 \\
+0.33\end{array}$ & $\begin{aligned} & 0.78 \\
+ & 0.3\end{aligned}$ & $\begin{array}{r}0.86 \\
+0.41\end{array}$ & NS \\
\hline 5 (PEG 400) & $\begin{array}{r}1.26 \\
\pm 0.52\end{array}$ & $\begin{aligned} & 1.22 \\
+ & 0.5\end{aligned}$ & $\begin{aligned} & 1.23 \\
\pm & 0.6\end{aligned}$ & $\begin{array}{r}1.32 \\
\pm 0.81\end{array}$ & $\begin{array}{r}1.99 \\
\pm 1.03\end{array}$ & $\begin{array}{r}1.99 \\
+1.06\end{array}$ & $\begin{array}{r}2.43 \\
\pm 0.71\end{array}$ & $P<0.02$ \\
\hline $6(30 \mu \mathrm{g}$ corticosterone $/ \mathrm{h})$ & $\begin{array}{r}0.74 \\
\pm 0.33\end{array}$ & $\begin{array}{r}0.82 \\
+0.41\end{array}$ & $\begin{array}{r}0.79 \\
+0.28\end{array}$ & $\begin{array}{r}0.66 \\
+0.17\end{array}$ & $\begin{array}{r}1.49 \\
+0.49\end{array}$ & $\begin{array}{r}1.83 \\
\pm 0.37\end{array}$ & $\begin{array}{r}1.78 \\
+0.48\end{array}$ & $P<0.001$ \\
\hline $7(10 \mu \mathrm{g}$ corticosterone/h) & $\begin{array}{r}2.52 \\
\pm 1.28\end{array}$ & $\begin{array}{r}2.46 \\
+0.98\end{array}$ & $\begin{array}{r}2.60 \\
\pm 1.29\end{array}$ & $\begin{array}{r}2.48 \\
\pm 1.06\end{array}$ & $\begin{array}{r}3.76 \\
\pm 1.39\end{array}$ & $\begin{array}{r}3.66 \\
\pm 1.14\end{array}$ & $\begin{array}{r}3.90 \\
+1.38\end{array}$ & $P<0.02$ \\
\hline
\end{tabular}

Animals received $0.5 \mathrm{ml} 0.15 \mathrm{M}-\mathrm{NaCl}$ at $0 \mathrm{~min}$ followed by $25 \mu \mathrm{g} \mathrm{LH}-\mathrm{RH} / \mathrm{kg}$ body weight $30 \mathrm{~min}$ later. Full details of experimental groups given in 'Materials and Methods'.

* Significant differences were based on the linear contrast of all mean pre-LH-RH injection values versus all mean post-injection values. $\mathrm{NS}=$ not significant.

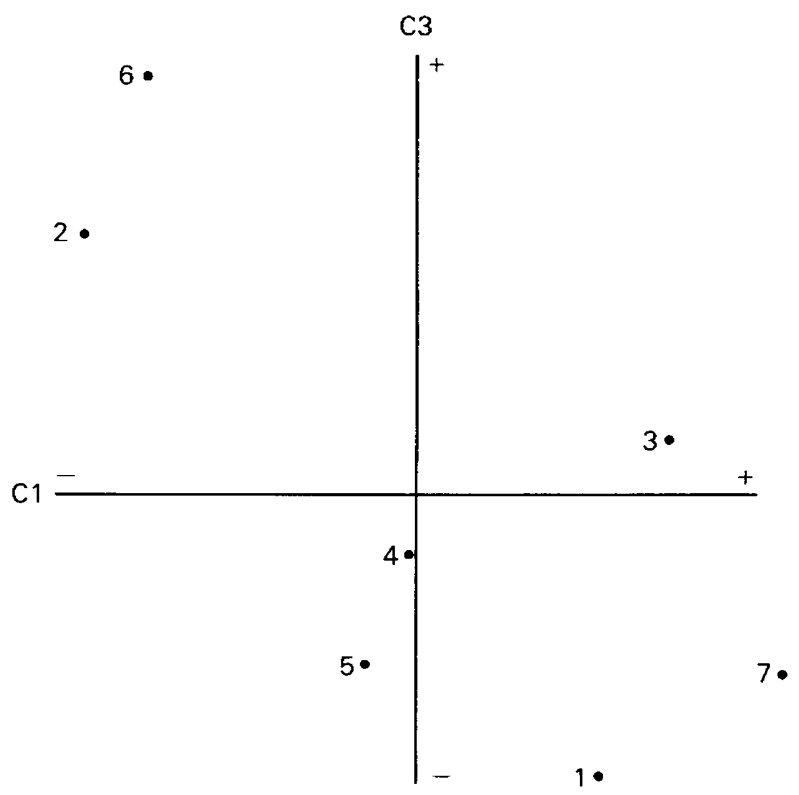

Text-fig. 1. Distribution of experimental groups produced by cartesian representation of principal components $C_{1}$ and $C_{3}$. These components account for $87.8 \%$ of the variance of the 3 raw data components: number of follicles in the $12-250 \mathrm{mg}$ range, slope and intercept of the regression of $\log$ hierarchy position on $\log$ follicular weight. $C_{1}$ is highly correlated with the number of follicles $(r=0.98)$ while $C_{3}$ is highly correlated with the slope $(r=0.9)$ and the intercept $(r=-0.89)$ of the regression line. Range of $C_{3}:-1.008$ to 1.466 ; range of $C_{1}$ : -0.271 to 0.254 . 
These results were reinforced by principal component analysis (Text-fig. 1) which produced a clear spatial separation of groups characterized by marked ovarian regression (Groups 2 and 6 ) and those with normal ovaries (Groups 1 and 7). This analysis, while not statistically discriminating, has the advantage of treating the ovarian hierarchy as a continuum and avoids the arbitrary creation of follicular classes.

\section{Hormone concentrations}

$L H$. At the start of the experimental treatments, there was a significant drop in mean plasma LH concentrations (Text-fig. 2) in Group $4(P<0.01)$, Group $3(P<0.005)$, Group $6(P<0.001)$ and Group $2(P<0.05)$. Group 2 plasma LH remained unchanged until Day 7 and declined thereafter. The infusion of $10 \mu \mathrm{g}$ corticosterone/h (Group 7) appeared to depress plasma LH but the effect was not significant. In Group 4 LH concentrations were significantly elevated when food was provided ad libitum on Days 10-14.

Corticosterone. Mean plasma corticosterone concentrations (Text-fig. 2) rose rapidly in Groups 4 and 6 ( $P<0.001$, both treatments), the rise being prolonged in Group 6 . After a longer delay, an increase in plasma corticosterone was also observed in Group 2 hens $(P<0.005)$. No significant rise in plasma corticosterone was observed in hens in Group 3 although the mean levels fluctuated more and were higher than those observed in birds in Groups 1, 5 and 7.

Progesterone. A significant fall in the mean plasma levels of progesterone (Text-fig. 2) was observed only in hens in Group $4(P<0.001)$, Group $6(P<0.001)$ and Group $3(P<0.02)$.

Oestradiol. A significant decrease in the mean plasma oestradiol concentrations (Text-fig. 2) occurred in hens in Group $6(P<0.001)$ within 1 day after implantation of the mini-pump, whereas the decrease in Group 2 hens $(P<0.02)$ occurred on Day 7 and thereafter. In Group 4 there was an immediate decline in mean plasma oestradiol levels $(P<0.001)$ followed by an increase on Day 9. No changes in mean plasma oestradiol levels were found in Group 5 hens. Plasma concentrations of oestradiol were not determined in Groups 3 and 7.

Pituitary gland response to $\mathrm{LH}-\mathrm{RH}$ (Table 2). Mean plasma $\mathrm{LH}$ concentrations were not significantly altered in any of the hens during the 30 -min control period after injection of saline. The subsequent administration of LH-RH resulted in a significant elevation of LH concentrations in hens in Group $1(P<0.001)$, Group 5 $(P<0.02)$, Group 6 $(P<0.001)$ and Group $7(P<0.02)$. The response was variable in hens in Groups 2 and 3; only $4 / 5$ birds in Group 3 and $3 / 5$ in Group 2 responded to the LH-RH. An increase in plasma $\mathrm{LH}$ concentrations after injection of $\mathrm{LH}-\mathrm{RH}$ was not observed in any of the hens in Group 4.

\section{Discussion}

The present results show that deprivation of food and water, feeding a low calcium or low sodium diet or infusing $30 \mu \mathrm{g}$ corticosterone/h caused regression of the ovary which was associated with a decline in the concentrations of $\mathrm{LH}$, progesterone and oestradiol. These results complement and extend previous reports by Scanes, Harvey \& Chadwick (1976) and Tanabe, Ogawa \& Nakamura (1981) on the effects of withdrawal of food and water and by Luck \& Scanes (1979) on the effects of low calcium diets.

The precise locus of the effects of nutritionally induced or corticosterone-induced ovarian regression cannot be determined from the present experiments. The ovary itself would not appear to be directly affected by deprivation of food and water, calcium or sodium because injections of gonadotrophins into fasted or calcium deficient hens will maintain egg production (Morris \& Nalbandov, 1961; Taylor, 1965). The pituitary gland may be a primary target of nutritionally induced ovarian collapse since the response to exogenous LH-RH was reduced or absent in hens deprived of food and water or fed diets deficient in calcium or sodium (Text-fig. 1). This 


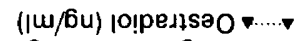
(ाm/6u) auodalsa6odd $z--\nabla$
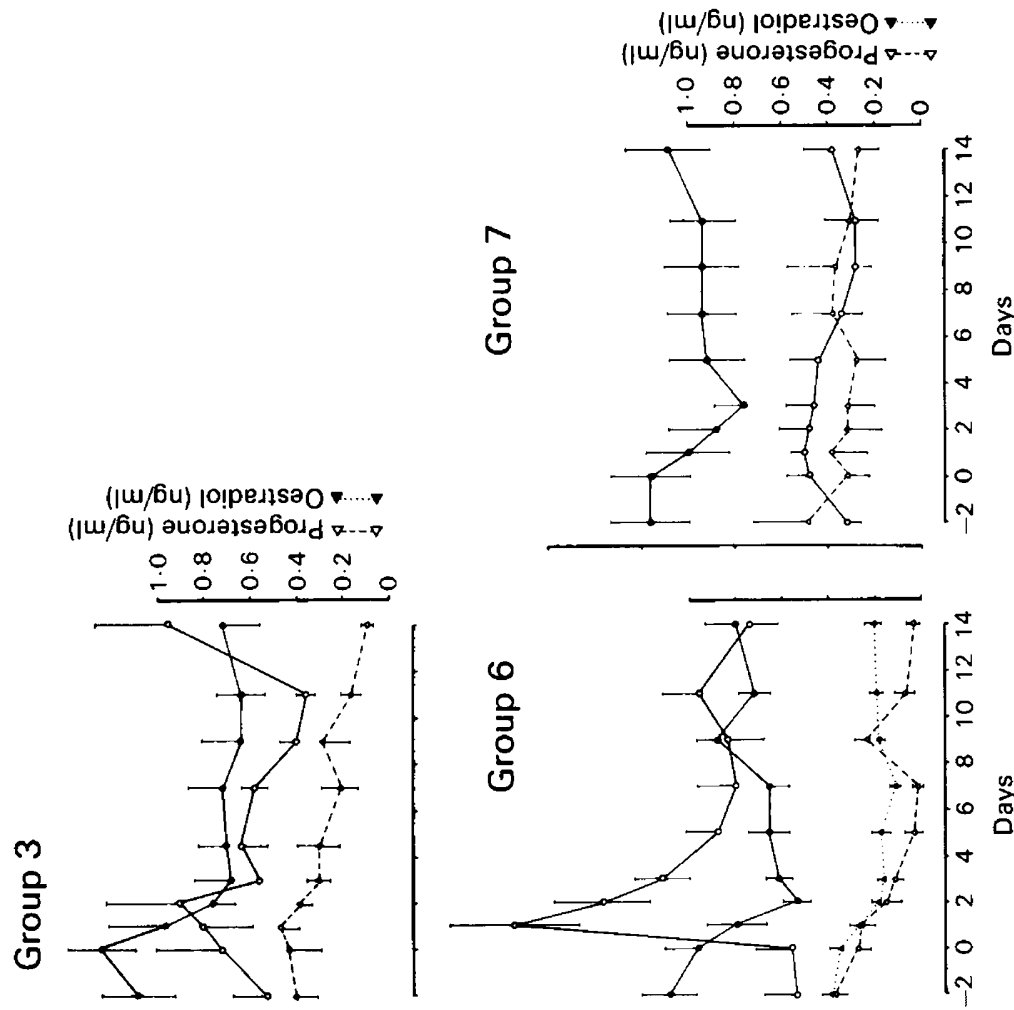

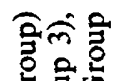

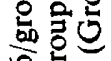

每

Z.

医总

클

윰용

ชิ

은

을.

के

응

(․ㅗ
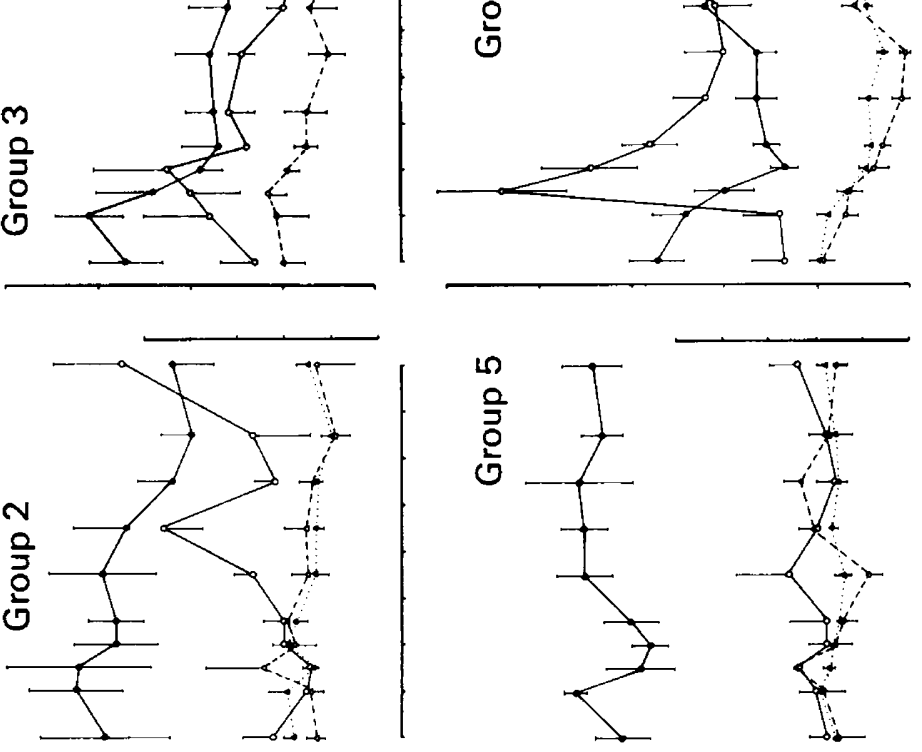

营

욕 묵

을은

\&

응응

兽政

능 종

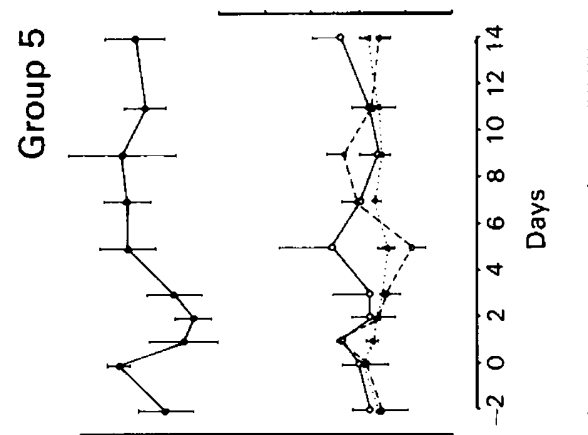

을 웡

$\rightarrow 0$

棺

을을을

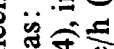

$0 \%$

골 은

帘

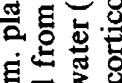
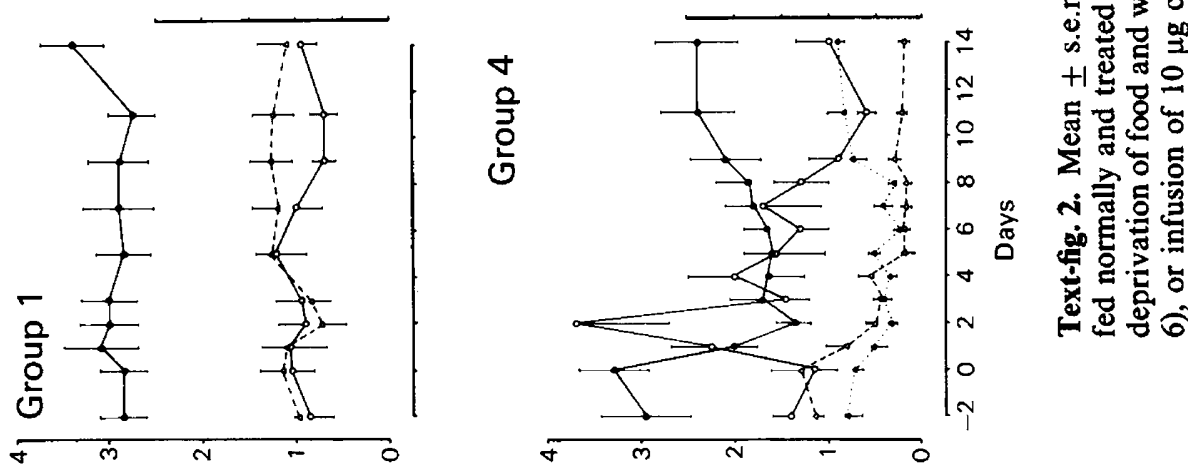

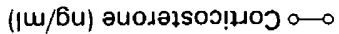

(ן $\mathrm{w} / 6 \mathrm{u}) \mathrm{H} 7 \bullet$ 
observation contrasts with the results of Luck \& Scanes (1979) who observed a substantial rise in the concentration of $\mathrm{LH}$ after the administration of LH-RH to calcium-deficient hens. This difference may be due to the degree of hypocalcaemia since Luck \& Scanes (1979) showed that plasma calcium declined for 12 days after the withdrawal of calcium from the diet. Another possible factor contributing to this contradictory response might be the degree of ovarian regression at the time of LH-RH treatment. Bonney \& Cunningham (1976) have shown that oestradiol enhances the production of LH in response to LH-RH in immature hens in vivo and by incubated dispersed pituitary cells. In the present experiments, the concentration of oestradiol was very low in the hypocalcaemic hens (Text-fig. 1) and the lack of response to LH-RH may therefore have been a secondary effect of ovarian regression.

The change in the responsiveness of the pituitary gland to LH-RH which accompanied nutritionally induced regression was not evident when corticosterone was infused at $30 \mu \mathrm{g} / \mathrm{h}$. After 12 or 13 days, a normal response was observed (Table 2) despite the fact that this infusion caused the most severe reduction in ovarian and oviduct weight (Table 1). Thus, changes in the sensitivity of the pituitary gland to LH-RH stimulation would not appear to be primarily involved in corticosterone-induced ovarian regression.

Luck \& Scanes (1979) showed that the release of LH after an injection of progesterone was diminished or non-existent in calcium-deficient hens, indicating that a change in hypothalamic sensitivity was responsible for ovarian involution in the presence of a calcium deficiency. Although a similar response was observed in the present study 12 days after the withdrawal of calcium from the diet (data not shown) it is difficult to ascribe ovarian regression to this change in hypothalamic sensitivity because it was accompanied by decreasing concentrations of ovarian steroids. Oestradiol and progesterone are known to be required for the maintenance of the positive feedback response to progesterone (Wilson $\&$ Sharp, 1976b) and therefore a normal response would not be expected in the absence of steroid production.

It is possible that a rising or elevated concentration of corticosterone is the common mediator of ovarian regression but this remains to be verified. Significant increases in plasma corticosterone followed fasting or the withdrawal of sodium from the diet but reduction of calcium had no significant effects.

A reduction in food intake as opposed to a reduction in a single dietary component may have been the major factor which precipitated ovarian involution since removal of calcium or sodium was associated with a decline in food consumption (Williams, Etches \& Rzasa, 1984). A similar relationship between dietary deficiencies in essential fatty acids and testicular regression has been reported for the cockerel (Engster, Carew \& Cunningham, 1978).

Withdrawal of food and water resulted in an immediate decline in plasma LH, progesterone and oestradiol; the concentrations of all of these hormones increased when normal feeding was resumed (Text-fig. 2; Tanabe et al., 1981). Progesterone is produced mainly by the largest ovarian follicle, and oestradiol chiefly by the small yolky follicles (Etches, 1983), suggesting that the ovarian regression that follows food deprivation is immediate and widespread throughout the hierarchy, affecting several follicles at once, while re-feeding involves a progressive re-establishment of the hierarchy of large follicles, as in the rat (Lintern-Moore, Everitt, Mariana \& Mauléon, 1981).

A further, important observation in this study concerning the hierarchy of ovarian follicles was that the number of normal follicles weighing more than $12 \mathrm{mg}$ was unchanged in hens whose ovaries had regressed. This suggests that, if follicles leave the hiearchy of the 1 st to the 40 th follicles by ovulation or atresia, they are replaced by others entering from the reserve of small $(<2.5 \mathrm{~mm}$ diam. or $12 \mathrm{mg}$ ) follicles. Therefore, when plasma LH levels are reduced to the values reported here, the final phase of follicular growth is blocked but the recruitment of small follicles continues.

Wilson \& Cunningham (1980) suggested that progesterone suppresses the pituitary-adrenal system in the hen because the injection of this hormone caused a rapid fall in plasma corticosterone concentrations. The above data reveal an inverse relationship between the plasma concentrations of these hormones in hens deprived of food and water, or fed diets deficient in calcium or sodium, 
since the plasma concentration of corticosterone rose as the concentration of progesterone fell. However, the decrease in plasma $\mathrm{LH}$ and progesterone after the infusion of $30 \mu \mathrm{g}$ corticosterone $/ \mathrm{h}$ indicates that adrenal secretions may depress the activity of the pituitary-ovarian axis. The hypothesis is supported by the fact that peripheral administration of corticosterone depresses plasma LH in the duckling (Deviche, Heyns, Balthazart \& Hendrick, 1979) and that hypothalamic implants of corticosterone reduce plasma $\mathrm{LH}$ in the photostimulated tree-sparrow (Wilson \& Follett, 1975). The common mechanism involved in the ovarian regression caused by the present experimental treatments may be the elevation of plasma corticosterone levels, produced directly by infusion of the hormone or indirectly by the noxious stimulus of food withdrawal or an unbalanced diet.

We thank Mr J.-D. Terlot for care of the animals and help with the experimental work; Mlle M. Garreau and Mme M. T. Durand for expert technical assistance; Dr F. J. Cunningham for materials used in the radioimmunoassay; and Mr P. Mongin, Director of the I.N.R.A. Station de Recherches Avicoles, for the facilities given to R.J.E. and J.R. during their sabbatical stay.

\section{References}

Bonney, R.C. \& Cunningham, F.J. (1976) The sensitizing effect of oestradiol on the response of the anterior pituitary gland of the domestic fowl to luteinizing hormone releasing hormone in vitro and in vivo. $J$. Endocr. 72, 16P, Abstr.

Deviche, P., Heyns, W., Balthazart, J. \& Hendrick, J. (1979) Inhibition of LH plasma levels by corticosterone administration in the male duckling (Anas palatyrhynchos). IRCS Med. Sci. 7, 622.

Dray, F., Terqui, M., Desforsses, B., Chauffaunier, J.M., Mowszowicz, I., Kahn, D., Rombauts, P. \& Gayle, M.S. (1971) Propriétés d'immunosérums anti 17 $\beta$ oestradiol obtenus chez différentes espèces animales avec l'antigène 17 $\beta$-oestradiol-6-O-carboxymethoxine sérum albumine de boeuf. $C$. $r$. hebd. Séanc. Acad. Sci. Paris, D 273, 2380-2383.

Duplaix, M., Williams, J. \& Mongin, P. (1981) Effects of an intermittent lighting schedule on the time of egglaying and the levels of luteinizing hormone, progesterone and corticosterone in the plasma of the domestic hen. J. Endocr. 91, 375-383.

Engster, H.M., Carew, L.F., Jr \& Cunningham, F.J. (1978) Effects of essential fatty acid deficiency, pair feeding and level of dietary corn oil on the hypothalamic-pituitary-gonadal axis and other physiological parameters in the male chicken. $J$. Nutr. 108 , 889-900.

Etches, R.J. (1976) A radioimmunoassay for corticosterone and its application to the measurement of stress in poultry. Steroids 28, 763-773.

Etches, R.J. (1983) Maturation of ovarian follicles. In Reproductive Biology of Poultry, (in press). Eds B. M. Freeman \& F. J. Cunningham. British Poultry Science, Edinburgh.

Etches, R.J. \& Croze, F. (1983) Plasma concentrations of $\mathrm{LH}$, progesterone and corticosterone during $\mathrm{ACTH}$ and corticosterone induced ovulation in the hen. Gen. comp. Endocr. 50, 359-365.

Etches, R.J. \& Cunningham, F.J. (1976) The effect of pregnenolone, progesterone, deoxycorticosterone or corticosterone on the time of ovulation and oviposition in the hen. Br. Poult. Sci. 17, 637-642.
Follett, B.K., Scanes, C.G. \& Cunningham, F.J. (1972) A radioimmunoassay for avian luteinizing hormone. $J$. Endocr. 52, 359-378.

Lintern-Moore, S., Everitt, A.V., Mariana, J.C. \& Mauleon, P. (1981) The effect of restricted food intake and refeeding on the ovarian follicular population of the pre-pubertal Wister rat. Reprod. Nutr. Develop. 21, 611-620.

Luck, M.R. \& Scanes, C.G. (1979) The relationship between reproductive activity and blood calcium in the calcium-deficient hen. Br. Poult. Sci. 20, 559-564.

Morris, T.R. \& Nalbandov, A.V. (1961) The induction of ovulation in starving pullets using mammalian and avian gonadotropins. Endocrinology 68, 687-697.

Scanes, C.G., Harvey, S. \& Chadwick, A. (1976) Plasma luteinizing hormone and follicle stimulating hormone concentration in fasting immature male chickens. IRCS Med. Sci. 4, 371.

Sharp, P.J. \& Beuving, G. (1978) The role of corticosterone in the ovulatory cycle of the hen. $J$. Endocr. $78,195-200$.

Soliman, K.F. \& Huston, T.M. (1974) Involvement of the adrenal gland in ovulation of the fowl. Poult. Sci. 53, 1644-1667.

Tanabe, Y., Ogawa, T.\& Nakamura, T. (1981) The effect of short-term starvation on pituitary and plasma $\mathbf{L H}$, plasma estradiol and progesterone, and on pituitary response to $\mathrm{LH}-\mathrm{RH}$ in the laying hen (Gallus domesticus). Gen. comp. Endocr. 43, 392-398.

Taylor, T.G. (1965) Calcium-endocrine relationships in the laying hen. Proc. Nutr. Soc. 24, 49-54.

van Tienhoven, A. (1961) The effect of massive doses of corticotrophin and corticosterone on ovulation in the chicken. Acta endocr., Copenh. 38, 407-412.

Williams, J.B., Etches, R.J. \& Rzasa, J. (1984) Induction of a pause in laying by corticosterone infusion or dietary alterations: the effects on the reproductive system, feed consumption and body weight. Br. Poult. Sci. (in press).

Wilson, F.E. \& Follett, B.K. (1975) Corticosteroneinduced gonadosuppression in photostimulated tree sparrows. Life Sci. 17, 1451-1456. 
Wilson, S.C. \& Cunningham, F.J. (1980) Concentrations of corticosterone and luteinizing hormone in plasma during the ovulatory cycle of the domestic hen after the administration of gonadal steroids. J. Endocr. 85, 209-218.

Wilson, S.C. \& Cunningham, F.J. (1981) Adrenocortical function and the ovulation cycle of the hen. Adv. Physiol. Sci. 33, 133-140.

Wilson, S.C. \& Lacassagne, L. (1978) The effects of dexamethasone on plasma luteinizing hormone and oviposition in the hen (Gallus domesticus). Gen. comp. Endocr. 35, 16-26.
Wilson, S.C. \& Sharp, P.J. (1976a) Effects of androgens, oestrogens and deoxycorticosterone acetate on plasma concentrations of luteinizing hormone in laying hens. J. Endocr. 69, 93-102.

Wilson, S.C. \& Sharp, P.J. (1976b) Induction of luteinizing hormone release by gonadal steroids in the ovariectomized domestic hen. J. Endocr. 71, 8798.

Received 22 April 1983 